\title{
AUGMENTED DÉRIVE AND CITY VISUALISATION
}

\author{
Tomás Laurenzo Coronel \\ City University of Hong Kong, School of Creative Media
}

\section{Javier Baliosian de Lazzari}

Universidad de La República, Instituto de Computación (Montevideo, Uruguay)

\section{Abstract}

In this paper we present an on-going research project that aims at constructing new modes of interaction with the city using poetic real-time data visualisations. The project uses a mapping device that measures and stores the intensity and direction of the signals coming from Wi-Fi access points and cellular antennae, together with two augmented reality prototypes that modify what their users see or hear. The prototypes created allow us to re-visit the city, intervening on our perception of it as well as allowing us to explore the geographical and perceptual disruption that arises when using one city's data onto another. The project, building on theoretical works by the Situationists, proposes an alternative to traditional cartographic representation, on the understanding that effective urban data-visualisation needs to incorporate the experience of living in a city, and not purely resort to abstract representation.

\section{Keywords: AUGMENTED REALITY; NETWORK; DRIFT; HEADS-UP DISPLAY; POET-} ICS OF SPACE

\section{AUGMENTED DÉRIVE AND CITY VISUALISATION}

\section{Resumen}

En este artículo presentamos un proyecto de investigación en marcha que pretende construir nuevos modos de interacción con la ciudad, a través de una visualización poética de datos en tiempo real. El proyecto utiliza un dispositivo de adquisición que mide y guarda la intensidad y dirección de las señales provenientes de puntos de acceso Wi-Fi y de antenas celulares, junto con dos prototipos de realidad aumentada que modifican lo que los usuarios ven o escuchan. Los prototipos permiten revisitar la ciudad interviniendo en nuestra percepción de ella, así como también explorar los efectos de mapear los datos de recabados en una ciudad sobre la percepción de otra. El proyecto, a partir de trabajos teóricos de los Situacionistas, propone una alternativa a la representación cartográfica tradicional, entendiendo que una visualización de datos urbanos efectiva requiere incorporar la experiencia de vivir en una ciudad, en lugar de basarse solamente en representaciones abstractas.

Palabras-clave: REALIDAD AUMENTADA; RED; DERIVA; CASCO DE VISUALIZACIÓN; POÉTICA DEL ESPACIO

Laurenzo Coronel, Tomás \& Javier Baliosian de Lazzari. 2016. “Augmented dérive and City visualisation”. AusArt 4(1): pp-pp. 217-226 DOI: 10.1387 /ausart.16706

\section{AUSART}




\section{INTRODUCTION}

"I am going to speak of Paris: not of its buildings, its churches, its monuments, its curiosities, etc., since enough has been written about them."

(Mercier [1781] 1998)

There is a long and rich tradition of artistic explorations of cities and urban environments. When Renaissance cartographers "sought to represent the world with ever more verisimilitude, artists adopted a newly singular point of view, a vantage point from which one might observe, project, and represent the world" (Hodges 2008).

Later, building on early theoretical and practical discourses by surrealists and situationists, artists have developed critical studies of cities and their cartographies, often finding alternative ways of engaging with and acting onto the city (Pinder 2005).

These "arts of urban exploration" (Pinder 2005) have not only created alternative modes of directly engaging with the city, but also have offered critical explorations of how cities are represented, allowing for an explicit representation of the political subtext inherent to the cartographic practice.

This explicitation of the politicality is particularly relevant as cartography is an "abstract and influential creative practice, rich with the power to engineer political views, religious ideas and even the material world itself" (Oliver 2008). In effect, maps are a contested practice embedding particular sets of power relations. Maps guide our perception of what the world is and steer our actions in it (Laurenzo 2013).

It is easy to agree that every cultural practice not only admits a political interpretation but also codifies a worldview and, therefore, carries a political stance. In this context, cartography becomes particularly interesting for it offers the only existent interface for perceiving large territories. If, as Paul Virilio says (1996), "totalitarianism is already present in the technical object", then the analysis of cartographical devices is not only tempting, but crucial.

In our project we focus on the tension, the cognitive distance, between the abstract, synthetic, and macro-scale perception of cities that cartographical 
representation offers, and the more visceral, human-centred experience of everyday life in the city.

As Robert Sennet puts it (2001, 15-21), "the experience of complexity is not just an external event", and the unavoidable reduction of cartography fails at representing and integrating this complexity; paraphrasing Mercier: we want to speak of Paris, not of its buildings.

Among the human-scaled artistic explorations of the city, the situationists' "dérives" are particularly well known. Situationist theorist Guy Debord defined the dérive as "a mode of experimental behaviour linked to the conditions of urban society: a technique of rapid passage through varied ambiances" (1958, 20-1).

We can see think of these unplanned journeys as implicit visualisations of the city. Under this point of view, visualisation can be thought not as an external process (a process that falls blindly in the fallacy of objectiveness) but instead as an internal, embodying process.

The dérive is then able to operate in two orthogonal axes, for the drift itself unfolds in a dual role: an experience and a tool for data gathering. The obtained data operates ex post facto as a visualisation of certain aspects of the city that become visible as a result of the dérive itself.

The visualisation can, then, be thought as both an experience and as the result of the experience. In other words, there are certain characteristics of the urban construction that require being experienced to become visible, and it is in the interaction between the city and its users -in the consumption of the city- that experience and visualisation converge. We cannot visualize without experiencing, and experiencing is visualizing.

The detection and understanding of hidden processes is a major objective of the social analysis of cities. To visualize processes like, for example, gentrification requires an understanding of the underlying socioeconomic currents that emerge as specific urban patterns. However, detecting the actors and motivations behind these processes has proven to be extremely difficult.

Within these difficulties, using the framework of capitalism, it is possible to structure an interpretation of the urban processes on the twin themes of accumulation and class struggle (Harvey 1978, 101-31). Extending this, we can 
-somewhat informally- model contemporary cities (contemporary because "early capitalism was frequently anarchic" (Sennet 2001, 15-21) as a collection of interconnected strata where urban social processes emerge from their interaction. This layer-based model of urban dynamics would incorporate social and economic layers, as well as physical, and service layers. According to Manuel Castells ([2002] 2011), "communication networks are the spatial attractors for the information economy", and the communication between strata determine the spatial structure.

Again, analysing the relation between these layers is complex, and also is complicated to identify causalities. An arbitrary example: what can we say about the relation between the decisions that shape a stroll in a city and the quality of the drinking water in that area? (The question might sound nonsensical at first, yet one could imagine that better water quality would be related with better infrastructure, which in turn would be related with more affluent population, modifying, in turn, the perception of safety, etc. However, one should note that these linear chains of cause-effect, are very often extremely reductionist).

How can we discover relations between indicators and their effects? (In our example, better water quality could contribute to gentrification, which, in turn could foster public investment, and so on).

Our project proposes a reflection on the visualisation of some of these layers, where visualisation is thought not only as an attempt at turning visible something invisible, but also as a creative and constructive process, and as a powerful research tool.

\section{THE MYTH OF VISUALISATION}

Marshal McLuhan's most famous phrase (1964) is aptly applicable to data visualisation: "the medium is the message", but also "the 'content' of any medium is always another medium. The content of writing is speech, just as the written word is the content of print, and print is the content of the telegraph".

Data visualisation suffers from the illusion of objectiveness. It purports itself as a probe that extracts data from "the reality" and offers it to our posterior inter- 
pretation. This fallacy is partially built on the ignorance of the political subtext of such activity.

There is, however, a great aesthetic potential on this construction of reality, and the craft behind this bridge -traversing from perceptual raw data to intra-mental representation - is perhaps what art is about: the construction of meaning as a reflection on language, cognition, and perception.

Viewed in this context, the psychogeographic dérive offers a rich political-aesthetic axis and "is contiguous to the political tradition of urban theory -from radicals like Henri Lefebvre (1947) to liberals like Jane Jacobs (1962)- which claims that random encounters in public spaces, often referred to as 'the Commons', are essential to the functioning of a democratic society" (Tuters 2004). The dérive situates itself on a rebellious role: it not only analyses the city but offers alternatives in our relationship with it.

If every visualisation is a political act (the very selection of the data to be visualised carries a political significance), then an embodied, subjective, internal, visualisation of the city is explicitly political. The city can be thought as a political concretion of an arrangement of living, and an "internal" visualisation showcases its subjectivity: the city becomes object and subject, both data source and canvas for its own human-embodied representation.

\section{AUGMENTED “REALITY”}

Urban perception mediated by mobile digital technology is not a new idea. The ".walk" project, for example, "combines computer code and psychogeographic streetwalking. During the walk, participants carry out an algorithmic series of instructions derived from computer code, that calculates the city as a giant 'peripatetic computer"' (Tuters 2004).

Art projects involving Augmented reality are also popular, with Oliver et al.'s Artvertiser $^{1}$ (a pair of AR goggles that superimpose artworks to advertising within the city) among the most well-known projects. 
Our approach, however, is built not only on the understanding of Augmented reality being a misnomer (for it is not the reality that we are augmenting) but also on the questioning of the role that the AR user is given.

Vilém Flusser ([1985] 2013, 66) characterised users as functionaries: people who dominate the apparatus by controlling its exterior, its interface, and are in turn dominated by the ignorance of its interior. Functionaries dominate a game for which they are not competent.

Similarly, traditional AR systems propose and assume users operating as functionaries. Our project, however, attempts at attacking both the illusion of an objective reality and the illusion of control.

The project consists of several cartographic prototypes based on AR. We have constructed a mapping device that allows us to register the intensity and location of network sources (Wi-Fi access points and cellular antennae). By using this device while performing an urban drift we gather data and populate a database with them.

The prototypes propose a metaphoric visualisation of these data -we build on the metaphor of wind, considering every network source as a "virtual wind" blowing on the city- turning a specific layer of urban infrastructure visible.

The prototypes use Augmented reality techniques to fusion the internal perspective of the situationist dérive with the abstract -external- representation of cartography, allowing to dynamically explore the aesthetics of visualisation while explicitly showing its power of affecting our understanding of reality.

It is in this reflection on reality itself where the chosen techniques show their value, questioning the underlying assumption of the camera's objectiveness. Assumption that not only is false but also oppressive, for it surrenders the operative definition of reality.

In Flusser words ([1985] 2013, 66), "the task of a philosophy of photography is to reflect upon this possibility of freedom -and thus its significance- in a world dominated by apparatuses".

The re-coding of visual reality is of particular interest to the authors; the art practice can be seen as an aesthetic investigation of the relationship between perception and intra-mental representation. 
Our use of media technology can also be described, in situationist terms, as a form of détournement, in which the (mis)appropriation and repurposing of conventions produce shifts in social consciousness (Shanken 2014).

\section{THE PROTOTYPES}

We have built a mapping device (based on a standard Android cell phone) that measures and stores the intensity and direction (using a metallic tube) of the signal coming from $\mathrm{Wi}-\mathrm{Fi}$ routers and cellular antennae, together with two prototypes of visualisation.

Using the mapping device, we perform walks in the city and construct a geo-referenced dataset, where for every point in our walk we store its position and the network information that the device captures.

We represent the captured data as a virtual wind. Every antenna and Wi-Fi access point contributes to the "wind field" from the direction of its signal. For all the points of the route we calculate the intensity and direction of the wind resulting from the combination of all the captured signals.

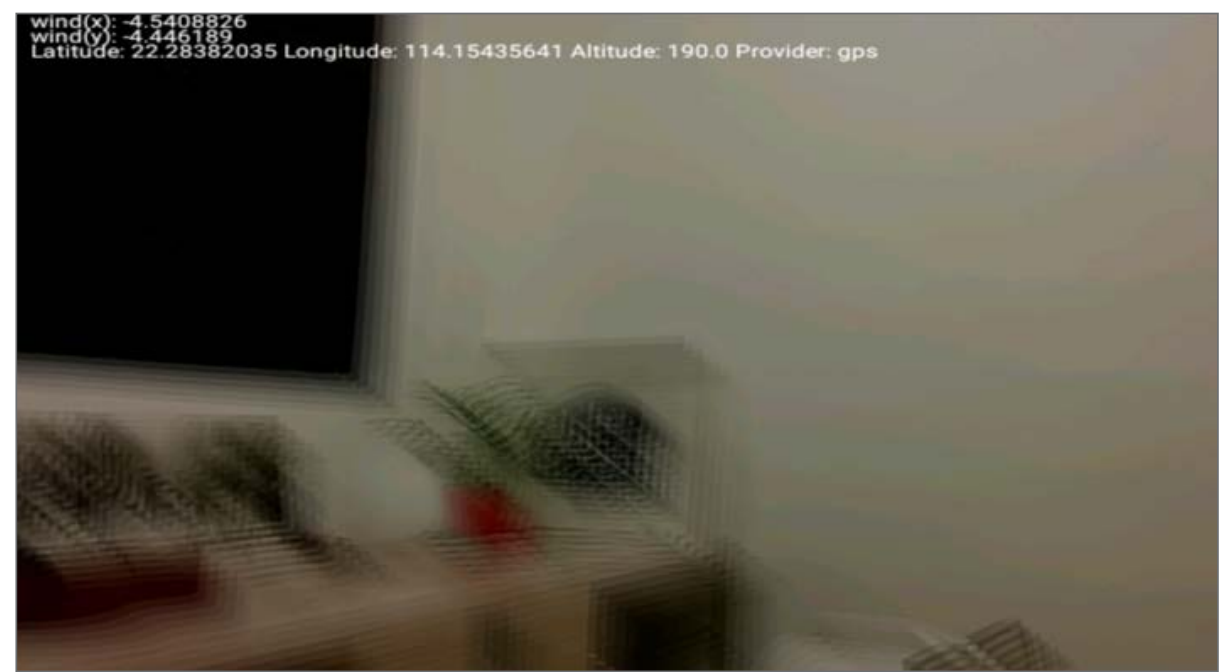

Figure 1. Screen capture of the graphical prototype. 
The prototypes created also run on Android phones. A first prototype synthetises the sound of wind, aurally representing the data field. The sound intensity is directly mapped onto the modulus of the vector resultant of combining all the network sources. We use a synthetic Head-Related Transfer Function (HRTF) to simulate the direction of the wind in a binaural signal.

A second prototype uses an augmented reality head-mounted display (HMD) to visually disrupt the city with a virtual wind. The head-mounted binocular display -based on a Google Cardboard HMD with an Android phones- shows in real-time the city as captured by the phone's camera (see Fig. 1), and the live video feed is distorted using the intensity and direction of the virtual wind as input data.

We have implemented a single-phone version (dividing the screen to provide faux-binocularity), and a two-phones version (see Fig. 2) using two phones' cameras for stereoscopy.

\section{CONCLUSIONS}

We can think of a city as a network, a human construction centred on communication. This project aims at reflecting on the city's identity, what makes it evolve, and what is the interpersonal linkage that makes it work. Moreover, what is the aestheticity of the relationship between geographical immediacy and the invisible networks of information transfer?

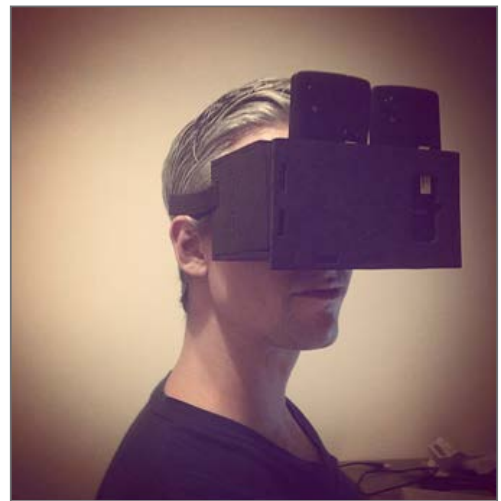

Figure 2. Google Cardboard-based HUD with two phones, providing stereoscopy.
If light is what allows us to see, we propose a humble torch that delves into some otherwise obscure aspects of the urban arrangement.

Our technologically mediated recreation of the situationists' drifts also aims at reclaiming the poetics of urban traversing in the city. City that exists in multiple layers that are not open for touring.

Turning visible the invisible also operates as an aesthetic reclaiming. This reclaiming, if effec- 
tive, should be emancipatory, for it allows us, subjects of the city, to define what is important, what is visible, and how it can be represented.

It aims at de-functionarising our operation of the city-device.

The project also explores the geographical and perceptual disruption that arises when using one city's data to modify another city's perception. For example, the dataset obtained on a dérive in Paris, is used to distort the perception of another drift in Hong Kong. What are the similitudes and differences? Can we think of an operational essence that is revealed by the visualisation?

In this sense, we propose not only new ways of traversing the city but also a synthetic construction, a meta-city that emerges from the cartographic practice. A reflection upon the ideal city that exists in the triviality of its pedestrian navigation.

\section{FUTURE WORK}

Much work is to be done to improve the existing prototypes and to create new ones, as well as on the philosophical and theoretical analysis of our proposal.

We have built prototypes based on one phone (and therefore using only one camera and not allowing for a binocular experience) and on two phones. Although our two-phone prototypes do offer a stereographic experience, we are to work on the aesthetics of the three-dimensional perception experience. We are already working on the development of 360-stereoscopic camera rigs that will provide hi-res immersive footage of the dérives.

Similarly, our phone-based prototypes offer relatively low resolution, diminishing the AR experience. Although this explicitation of the artificiality of the image plays a role in the visualisation process, we will explore higher-resolution headmounted displays within this project.

In spite of this, we should remain aware that -quoting again- image-capturing devices produce "camera memories, not information, and the better they do it, the more they prove the victory of the camera over the human being". 


\section{References}

Castells Oliván, Manuel. (2002) 2011. The Information Age: Economy, Society and Culture. Vol. I: The rise of the Network Society. Hoboken, NJ: Wiley-Blackwell

Debord, Guy. 1958. "Thèses sur la Révolution Culturelle." Internationale Situationniste 1

Flusser, Vilém. (1985) 2013. Filosofia da Caixa Preta: Ensaios para uma futura filosofia da fotografía. São Paulo: Annablume

Harvey, David. 1978. "The urban process under Capitalism". International Journal of Urban and Regional Research 2(1-4): 101-31

Hodges, Elisabeth. 2008. Urban Poetics in the French Renaissance. Aldershot UK: Ashgate

Laurenzo Coronel, Tomas. 2013. "Decoupling and context in New Media Art". Tesis Univ. La República (Uruguay), Programa de Desarrollo de las Ciencias Básicas/PEDECIBA

McLuhan, Marshall. 1964. Understanding Media: The extensions of man. New York: New American Library

Mercier, Louis-Sébastien. (1782) 1998. Tableau de Paris. Paris: La Decouverte

Oliver, Julian. 2008. "Cartofictions: Maps, the Imaginary and GeoSocial Engineering". Discurso inaugural de Inclusiva-Net, Madrid '08". Vídeo de Vimeo, 01:03:03. 14 de marzo. https:// vimeo.com/784263

Pinder, David. 2005. "Arts of Urban Exploration". Cultural Geographies 12 (4): 383-411. doi: 10.1191/1474474005eu347oa

Sennett, Robert. 2001. "Capitalism and the City". En Cities for the New Millennium, edited by Marcial Echenique \& Andrew Saint. 15-21. London: Spon

Shanken, Edward A. 2014. Art and Electronic Media. London: Phaidon

Tuters, Marc. 2004. "The locative commons: Situating location-based media in urban public space" Paper presented at 2004 Futuresonic Conference

Virilio, Paul. 1996. "Global Algorithm 1.7: The Silence of the Lambs: Paul Virilio in conversation". By Carlos Oliveira, translated by Patrice Riemens. Ctheory.net, 12 Junio. http://ctheory.net/ global-algorithm-1-7-the-silence-of-the-lambs-paul-virilio-in-conversation/

Notes

${ }^{1}$ The Artvertiser (Julian Oliver, Diego Diaz, Clara Boj \& Damian Stewart, 2009-2010), action installation interactive. 